\title{
Mediating Role of Innovations as a Factor of Firm's Competitiveness ${ }^{1}$
}

Received: 08.04.2021

Available online: 29.09.2021

\section{Zhelyu Vladimirov*}

\begin{abstract}
The goal of this paper is to clarify conceptually the role of innovations as a firm's competitiveness factor. Particularly, it aims to reveal how the innovations mediate the impact of innovation antecedents and determinants on performance. The paper is based on the achievements of the basic theories of competitiveness such as activitybased view, resource-based view, dynamic capability view, configuration approach, and innovation studies. As a conceptual paper it tries to identify previously unexplored connections between some constructs.
\end{abstract}

The paper proposes a conceptual model which links the influence of the firm's internal and external factors on both innovations and performance, with the innovations' own impact on performance. In this case the innovations mediate the performance effects of the preceding factors. The interrelation of different types of innovation implies also that innovations can influence performance directly or indirectly (through their interaction).
The paper is restricted to the analysis of selected theories which are considered as most relevant to the study of the firm's competitiveness. It is acknowledged that other economic and institutional theories can also contribute to this topic.

The implications for managers are that developing some basic factors that impact both innovations and performance, may lead to both higher innovativeness and competitiveness.

Keywords: firm's competitiveness, theories, factors, innovations, mediation

JEL: 030; 031

\section{Introduction}

The capacity of firms to create and maintain a competitive advantage has long been investigated (Prahalad and Hamel, 1990; Porter, 1998; Barney, 1997). There are different definitions of competitiveness, depending on the level of analysis: macro (nation), mezzo (regional, industry or cluster of firms), and micro (firm) level. Respectively, there are macro- and micro-level theories, and macro- and micro-level measures for competitiveness (Siudek and Zawojska, 2014, pp. 93-95). This paper considers only theories related to the competitiveness at a micro (firm) level.

\footnotetext{
1 This article was funded by the Marie Curie Actions (IEF within the FP7 of the EU) under GA No 327405.

Professor, Sofia University St Kliment Ohridski, Faculty of Economics and Business Administration, 1504, Sofia, 15 Tsar Osvoboditel Blvd.
} 


\section{Articles}

In a narrow sense the firm competitiveness is a firms ability to perform better than other companies in the same industry (Lall, 2001). It is synonymous to a firm's longterm positive performance, which explains its measurement by financial and nonfinancial performance indicators (Buckley et al., 1988). Many researches on firm competitiveness, however, use the term more broadly by seeking to identify the factors influencing it (Fagerberg, 1996). The IMD and WEF (1993) define competitiveness as a multidimensional construct which includes a combination of factors (assets, capabilities, and environmental conditions) that determine the firm's performance.

The literature review on firm competitiveness identifies two major streams of studies. The first stream investigates the antecedents and determinants of firm performance without considering the role of innovations, while the second one includes innovations. The first stream is based on the theories of firm-level competitiveness such as: industrial organization (IO), resource-based view (RBV), dynamic capabilities view (DCV), configuration approach, and entrepreneurship theories (Porter, 1998; Barney, 1991; Teece et al., 1997; Miller, 1996; Ferreira et al., 2017).

It is widely accepted that Porter's framework, derived from the 10 theory, focuses mainly on external (industry-level) characteristics, while the RBV underlines the role of the firm's internal resources. These approaches can be combined because at least they reveal the two sides of the firm external and internal (Wernerfelt, 1984). The two concepts provide also similar recommendations on how firms can gain a competitive advantage - through the unique combination of resources and capabilities (Grant, 2002, p. 139), or through continuous
Mediating Role of Innovations as a Factor of Firm's

Competitiveness

innovations (Porter, 1991, p. 111). As the sources of competitiveness are multiple and cannot be confined to one group of factors, the combinations of different factors refer to the configuration approach (Fiss, 2007).

The necessity of firm innovation is determined by the increased global competition, under which the more innovative firms tend to have higher performance (Artz et al., 2010). Therefore, to sustain the new competition pressure the firms need to develop their innovation capabilities (Rajapathirana and Hui, 2018). The previous studies reveal that similar to the firm competitiveness theories such as RBV, knowledge-based view, organisational learning, network theory, and organisational culture, are used to explain the innovation antecedents and determinants (Crossan and Apaydin, 2010; Chatzoglou and Chatzoudes, 2018).

The bridging of competitiveness and innovation literatures is based on the fact that the same groups of factors (internal and external) serve as antecedents and determinants of both innovations and performance. Hence being determined by the firm's internal and external factors and having their own impact on performance, innovations mediate the influence of some of these factors on performance. Although the innovation is a determinant factor of competitiveness (Srivastava et al., 2017), very few studies link simultaneously innovation antecedents, innovation itself, and organizational performance outcomes (Vincent et al., 2004, p. 13). The lack of such studies compounds the difficulties of understanding the relative impact of innovations on performance in comparison to other factors. According to Mytelka (1999), there is still a gap in terms of competitiveness and the role of innovation in it. 


\section{Articles}

The present paper aims to fill this gap by proposing a conceptual model which links the effects of the firm's internal and external factors on both innovation and performance, with innovation's own impact on performance. In particular, the paper seeks to reveal new relationships among well-known constructs by developing a logical argumentation about these associations. As a conceptual paper, it falls under the category of "model paper", which tries to identify previously unexplored connections between constructs (Cornelissen, 2017). For that reason, the paper uses a literature review as a necessary tool, but not as an ultimate objective (Jaakkola, 2020, p. 21). The goal is to explain the mediating role of innovations as a firm's competitiveness factor and to propose new associations between studied constructs. Specifically, the paper addresses the following research questions:

1. Are the same groups of factors antecedents or determinants of both innovations and performance?

2. Do the innovations mediate the impact of some of these factors (which influence both innovations and performance) on performance?

Based on previous research, the paper proposes a model of firm competitiveness factors, in which these factors are situated on two levels. The first level includes the firm internal and external characteristics, while the second level supplements innovation-related factors. Both the innovations and performance depend on the first level factors, and if the innovations have their own influence on performance, these mediate the performance impact of some of the preceding factors. The interrelation of different types of innovation suggests also that innovations can influence performance directly or indirectly (through their interaction).

The paper has four sections containing: firm's external and internal competitiveness factors; innovation antecedents and determinants, innovation-performance relationships, mediating role of innovation; conceptual model, proposals, and discussion; and conclusion.

\section{External and internal} competitiveness factors at the firm level

The review of the literature on competitiveness factors at the firm level shows that the most relevant and used theories are M. Porter's concept, RBV, DCV, and configuration approach (Man et al., 2002; Siudek and Zawojska, 2014; Momaya, 2019). The choice of these theories is based on their ability to address some previously untested relationships between studied constructs.

\subsection{External competitiveness factors (Porter's framework)}

The starting point of Porter's view on competitiveness is the relentlessness of the environmental changes to which firms have to respond mainly through innovation and upgrading (Porter, 1991). He develops the concept of five market forces, which influence firm competitiveness on the levels of industry, strategic group, and individual firm (Porter, 1998, p. 4). Subsequently, the industry structure is systematized into four components (Porter's diamond): factor conditions; demand conditions; related and supporting industries; and industry strategy, structure and rivalry. Government effects and chance events constitute two additional components in the model. Porter (1996) proposes also an important difference between the firm's operational and strategic 


\section{Articles}

performance. Operational effectiveness stresses on achieving excellence in individual activities, while strategy concentrates on genius combinations of activities (innovations).

\subsection{Internal competitiveness factors (RBV)}

The RBV refocuses the attention on the firm's internal tangible and intangible resources as the most important sources of competitiveness (Wernerfelt, 1984; Barney, 1991). According to this concept, some resources (production factors) are inelastic in supply, which constitutes a source of sustained competitive advantage. A firm has a competitive advantage if its resources are valuable, rare, immobile and non-substitutable (VRIN framework). However, the simple possession of resources is insufficient for realizing such an advantage - important is how these resources are used (Mahoney and Pandian, 1992). For this reason, Barney (1997) transforms the VRIN framework into a VRIO model, adding the capacity of organizations to use the resources. Many authors consider that intangible resources influence more significantly firm success than tangible ones (Galbreath, 2005; Kamasak, 2017). These resources include assets (something that the firm "has") and capabilities (something that the firm can "do") (Hall, 1992). Therefore, capabilities refer to the firm's capacity to deploy resources and to create a new configuration of resources that can sustain a competitive advantage (Wang et al., 2015).

The RBV is criticized for some limitations. For instance, Black and Boal (1994) suggest that no single resource, but rather their combinations explain better the firm's performance. The RBV is also criticized for neglecting the role of entrepreneur for performance, which is particularly important
Mediating Role of Innovations as a Factor of Firm's

Competitiveness

for smaller firms (Foss et al., 2007). As the RBV cannot explain the firm's advantages in the situations of rapid changes (Teece and Pisano, 1994, p. 537), the dynamic capabilities view (DCV) has been developed.

\subsection{Internal competitiveness factors (DCV)}

Teece et al. (1997, p. 516) define dynamic capabilities as "the firm's ability to integrate, build and reconfigure internal and external competences to address rapidly changing environments". Particularly significant is the distinction between ordinary ("zero-level") and dynamic ("higher-level") capabilities (Collis, 1994). If the ordinary capabilities are "operating routines", dynamic capabilities are concerned with change (Winter, 2003). Despite the importance accorded to dynamic capabilities, Eisenhardt and Martin (2000) contend that competitive advantage does not rely on these per se, but on the resource configurations created by them. Dynamic capabilities do not involve the production of goods or services, rather they help a firm to adapt ordinary capabilities to the changing environment (Helfat and Peteraf, 2003).

\subsection{Configuration approach}

According to Miller (1996), both Porter's competitive analysis framework and the RBV can be extended by searching for the most successful configurations of organizational elements. The configuration approach views the organization as an entity of complex relationships amongst interconnected variables, grouped in respective domains (Meyer et al., 1993). This approach aims to identify groups of firms that share common features on some important dimensions. The approach overcomes some shortages of the linear paradigm (Fiss, 2007, p. 1181), although it cannot reveal the interaction 


\section{Articles}

among variables, including the mediating role of innovations.

\subsection{Combining different approaches}

The integration of the activity-based view and the RBV (incl. DCV) is justified by the fact that the two perspectives reveal the two sides of the firm - external and internal (Wernerfelt, 1984, p. 171). According to Newbert (2007, p. 122), “while a firm's performance is driven directly by its products, it is indirectly (and ultimately) driven by the resources that go into their production." Other authors also agree that the RBV and Porter's perspective are complementary (Gellweiler, 2018). As Sarasvathy (2004) suggests, a shift in competitiveness research is needed to overcome the separated analysis of the impact of internal and external factors on performance towards the interaction between them. Gupta et al. (2013) propose a framework of internal and external environmental factors, which influence the growth patterns of SMEs. The firm level competitiveness factors under these approaches are presented in figure 1.

\begin{tabular}{|l|c|l|}
\hline $\begin{array}{l}\text { 1. Internal factors (Tangible } \\
\text { resources; intangible resources } \\
\text { (assets and capabilities); } \\
\text { entrepreneur's characteristics and } \\
\text { orientations; strategy; structure), } \\
\text { etc. }\end{array}$ & $\begin{array}{c}\text { 3. Combinations } \\
\text { of internal and } \\
\text { external factors }\end{array}$ & $\begin{array}{l}\text { External factors (Factor } \\
\text { conditions; demand conditions; } \\
\text { related and supported } \\
\text { industries; industry structure, } \\
\text { rivalry; government effects; } \\
\text { chance events), etc. }\end{array}$ \\
\hline \multicolumn{2}{|l|}{} & \\
4. Competitiveness (increase/decrease in sales, market share, revenues, etc.)
\end{tabular}

Figure 1. Internal and external competitiveness factors at a firm level

Figure 1 visualises the impact of firm internal and external factors and their combinations on competitiveness. The internal factors refer to the firm's tangible and intangible resources, entrepreneurial/managerial characteristics, and firm strategies and structures, while the external ones encompass Porter's "diamond" factors. Competitiveness is measured often by some (objective or perceptual) performance indicators such as growth in sales, market share, profit, etc. (Buckley et al., 1988). In order not to complicate the schema, not all of the relationships among its components are displayed. For example, external factors are interrelated, which is implicitly assumed, but not reflected in figure 1. Changes in government policies may affect all other factors, and the same applies to changes in demand conditions, factors conditions, etc. Internal factors also interact with each other. Firms with different capabilities may use similar assets differently, and similar assets may impose different constraints on capabilities.

\subsection{Empirical studies on competitiveness under the main theories}

There is a considerable empirical research on firm level competitiveness, which is based on Porter's framework, RBV, DCV, and configuration approach. Other studies use more complex models to examine the joint impact of internal and external factors on firm competitiveness (Appendix 1, Table 1).

The unifying moment of DCV, Porter's view, and configuration approach is that these underline the importance of combination 


\section{Articles}

and recombination of firm resources to performance (Zahra et al., 2003, p. 166; Porter, 1991, p. 108; Miller, 1996, p. 508). Therefore, the joint application of these theories suggests to include new factor combinations (innovations) (Edquist, 2001) as a determinant of the firm level competitiveness.

The problem that arises, however, is that innovations are often included in such models at the same level of analysis as the innovations' antecedents and determinants. The issue derives from the fact that the same groups of factors (internal and external) serve as antecedents or determinants of both innovations and performance, along with the innovation own influence on performance. In order to address this problem, the innovation antecedents and determinants, the innovationperformance relationships, and the mediating role of innovations will be analysed.

\section{Innovations as a firm's competitiveness factor}

\subsection{Definitions, types and interaction of innovations}

The innovation is defined broadly as "the adoption of an idea or behavior, whether a system, policy, program, device, process, product or service, that is new to the adopting organization" (Damanpour, 1991, p. 556). Unlike invention, the innovation reflects both adoption and commercialization of a new idea (Jiménez-Jiménez and Sanz-Valle, 2011).

According to Schumpeter (1934), the entrepreneurs may introduce new combinations of production factors in the forms of: new product, higher quality of an existing product, new production methods, new markets, new sources of raw materials, or new organizational forms. Subsequently the Oslo Manual has synthesized different
Mediating Role of Innovations as a Factor of Firm's

Competitiveness

innovations into four types: product/ service, process, marketing, and organizational innovations, along with the fundamental distinction between incremental and radical innovations (OECD, 2005, p. 58).

Most of the innovation studies deal with product innovations and to a lesser degree with process ones (Keupp et al., 2012). The process innovations focus mainly on technological changes, while the organizational innovations deal primarily with people and the organisation of work (OECD, 2005 , p. 55). Marketing innovations refer to the significant changes in product design or packaging, product placement, product promotion or pricing (OECD, 2005, p. 49).

Although the existing researches suggest that different types of innovations are closely interrelated (Piening and Salge, 2015), there are few studies investigating the interdependence of types of innovations (Gunday et al., 2011). For example, Lee et al. (2019) find that process innovation supports both radical and incremental product innovation. The results of other studies demonstrate that there is a strong interdependence, complementarities, and mutual support between product and different process innovations (Damanpour et al., 2009; Hullova et al., 2016). This complementarity, however, is different among different types of innovation (Ballot et al., 2015).

\subsection{Internal antecedents and determinants of innovation}

Although the innovation antecedents and determinants differ, they tend to cluster around two groups: internal and external to the firm (Damanpour, 1991, p. 557; Souitaris, 2003 , p. 519). The internal antecedents and determinants refer to the firm's tangible and intangible resources, entrepreneur/manager orientations, and their combinations. These 


\section{Articles}

factors are reflected by the RBV, DCV (Crossan and Apaydin, 2010), and entrepreneurship studies. For example, Becheikh et al., (2006) identify seven internal groups of variables, which influence innovation: characteristics of the firm, strategies, structure, control, culture, top management, and functional assets. Julienti et al., (2010) reveal the significance of firm tangible resources (access to capital, location of buildings, etc.) and intangible assets and capabilities (knowledge, skills, reputation, and entrepreneurial orientation) for product innovation performance.

McAdam et al., (2014) highlight the particular role of knowledge factors for innovation. The significance of knowledge as an innovation resource is reflected in the concepts of absorptive capacity (Cohen and Levinthal, 1990) and networking (Lavie, 2006). Therefore, the sustained competitive advantage may be created from network capabilities (Ritter and Gemünden, 2003) and organisational learning (Wang et al., 2010, p. 175). Particularly important for learning is the firm's R\&D capacity and experience (Grimpe and Kaiser, 2010). Tang and Murphy (2012) show that the largest stream of innovation research emphasizes knowledge, skills, and competencies that are encompassed by the human capital theory. Linked to this theory, many researches reveal that the entrepreneur is a key figure for innovations in small enterprises (Oksanen and Rilla, 2009; Rosenbusch et al., 2011). Other internal determinants of innovation include: firm size; age, structure; strategies; marketing; advanced technology; participation of foreign capital, etc. (Becheikh et al., 2006, p. 651) (Appendix 1, Table 2).

\subsection{External antecedents and determinants of innovation}

External antecedents and determinants of innovation refer to government regulations, labour market, and institutional environment. These factors are similar to those in Porter's diamond model, with a greater emphasis again on knowledge and networking. Some of the works in this field relate to national innovation systems (Lundvall, 1998), or innovation in clusters and geographical innovation systems (lammarino and McCann, 2006; Ketels, 2013). Culture also plays a significant role in the firm's innovativeness as some organizational cultures contain more barriers to novelties (Hernández-Mogollon et al., 2010).

The importance of external factors is central to the notion of open innovation (Chesbrough et al., 2006; Bogers et al., 2017). It assumes that enterprises cannot conduct all the R\&D activities, and have to resort to external knowledge. This knowledge is necessary for both the generation of internal and the adoption of external innovation in terms of technology, product, policy or practice (Walker et al., 2015). Aldieri et al. (2018, p. 39) reveal that firms that are closer to the world technology frontier tend to benefit more from knowledge spillovers. The concept of open innovation includes in- and outgoing of the firm movements of technology and ideas, called also "technological exploration" and "technological exploitation". The organizations with sustainable competitive advantages are those which can balance the two aspects ("organizational ambidexterity") (Raisch et al., 2009). Other external factors for innovation are: the industry sector; location and region; access to both information and finance; intellectual property rights protection; government policies; internationalisation, etc. (Hong et al., 2012, p. 435) (Appendix 1, Table 2). 


\section{Articles}

\subsection{Combining internal and external antecedents and determinants of innovation}

Chang et al. (2011) state that a few empirical researches have examined the combinations of internal and external antecedents of innovation. López-Fernández et al. (2011) also find that the identification of joint effects of internal and external factors is relatively new in the firm innovation literature. According to Gupta et al. (2013), there should be empirical research on how internal and external factors contribute to sustainable firm's innovativeness. Vega-Jurado et al. (2008, p. 631) consider that the methodological difficulty to integrate theoretical perspectives has led researchers to analyse separately external characteristics and the firm's internal capacities as determinants of innovation. The results of their research, however, show that the models which include two types of factors, explain innovative performance better than models with only one type of factors.

Other studies also demonstrate the significance of investigating the combined effect of internal and external factors on innovations. According to Naranjo-Gil (2009), combining the two groups of factors leads to a better understanding of the antecedents of innovation. Love and Roper (2015) base their review of the links between the small firms' innovation, export and growth on firm internal and external enablers. Carayannis and Wang (2012) conclude that both firmlevel characteristics and national innovation systems are key factors in the firm's innovation capacities (Appendix 1, Table 2).

\subsection{Innovations and firm performance}

The empirical studies on the performance effects of innovations exhibit contradictory
Mediating Role of Innovations as a Factor of Firm's Competitiveness

results. The findings reveal positive ( $\mathrm{Ngo}$ and O'Cass, 2013), negative (Simpson et al., 2006), and even a lack of such relations (Zaied and Affes, 2016). This can be explained by the fact that the "innovation-performance" relationship is context dependent as the performance is influenced by both innovations and other internal and external factors (Rosenbusch et al., 2011, p. 441). Many researches find that product innovations are positively associated with firm performance and growth (McNally et al., 2010; Ramadani et al., 2019). According to Fagerberg et al. (2004), while the new products generally have a positive effect on the firm's growth, the effects of process innovations are not so clear. Other studies, however, reveal that process innovations may contribute to firm performance (Piening and Salge, 2015).

The positive influence of both organizational (Azar and Ciabuschi, 2017) and marketing (Gupta et al., 2016) innovations on the firms' performance is also demonstrated. Lin and Chen (2007) consider that organizational innovations rather than technological ones seem to be the most important factor for total sales. Focusing on a single type of innovation activity hinders the potential advantages resulting from the synergy effects of diverse innovation activities (Lee et al., 2019). Other studies also indicate that the synchronous coadoption of organizational and technological innovations is positively related to innovative performance (Hervas-Oliver et al., 2014) (Appendix 1, Table 3).

\subsection{The mediating role of innovations}

The review of the literature leads to the conclusion that both competitiveness and innovation depend on the same groups of 


\section{Articles}

internal and external factors. When innovation also influences performance, it becomes a mediator between some of the environmental and organizational antecedents and performance. A few studies, however, link both innovation antecedents and innovation itself to performance. Empirical studies have used either innovation outcomes or performance as a dependent variable, while including both of these in a model would reveal the mediation role of innovation between innovation determinants and firm performance (Crossan and Apaydin, 2010, p. 1176). The lack of such studies limits our understanding of the relative weights of innovations on performance in comparison to other factors.

Vincent et al. (2004) demonstrate that the innovation serves as a link between certain antecedents and financial performance, thereby supporting the partial mediation model. In addition, competition, age, and organizational resources have both direct and indirect (through innovation) relationships with performance. Allred and Swan (2005) reveal that the relationships between industrial dynamism and a country's patent protection and the firms' performance are mediated by the firms' investment in innovation. According to Kostopoulos et al. (2011), the innovation performance mediates fully the influence of external knowledge and absorptive capacity on financial performance. Hoonsopon and Ruenrom (2012) find that radical and incremental product innovation mediate the impact of both culture and structure on marketing and financial performance. The study of Wang and Lin (2013) show that organizational innovation partially mediates the relationship between knowledge management orientation and performance.
Peña-Vinces et al. (2012) demonstrate the mediating role of technological innovation (the ICT use) as a factor enhancing the international competitiveness of small firms. The results of Uzkurt et al. (2016) reveal that product innovation mediates the relationship between environmental uncertainty and firm performance.

Other studies on the mediating role of innovations consider the relationships between the firm's strategic orientations such as: market, entrepreneurial, and learning orientations ( $\mathrm{MO}, \mathrm{EO}$, and $\mathrm{LO})$ and performance. For example, Keskin (2006) finds that MO indirectly impacts firm performance via firm innovativeness and learning orientation, while firm innovativeness positively and directly affects firm performance. According to Jiménez Jiménez et al. (2014), LO and radical innovation mediate completely the influence of EO on performance. Radical innovation mediates partially the impact of LO on performance, while LO and radical innovation influence firm performance directly and positively. Kollmann and Stöckmann (2014) show that both the explorative and the exploitative innovations mediate the influence of EO on firm performance. Chang et al. (2014) demonstrate that the radical and incremental innovations play differential mediating roles in manufacturing and service firms with respect to the "MO-performance" relationship (Appendix 1, Table 4).

\section{Conceptual model, proposals, and discussion}

Based on these studies, the following conceptual model on the mediating role of innovations as a firm's competitiveness factor is proposed (Fig. 2). 


\begin{tabular}{|l|l|l|}
\hline $\begin{array}{l}\text { 1. Internal factors } \\
\text { (Tangible resources; } \\
\text { intangible resources } \\
\text { (assets and capabilities); } \\
\text { entrepreneur's } \\
\text { characteristics and } \\
\text { orientations; strategies; } \\
\text { structure), etc. }\end{array}$ & $\begin{array}{c}\text { 3. Combinations } \\
\text { of internal and } \\
\text { external factors }\end{array}$ & $\begin{array}{l}\text { External factors (Factor conditions; } \\
\text { demand conditions; related and } \\
\text { supported industries; networking with } \\
\text { suppliers, customers, and partners; } \\
\text { knowledge acquisition; industry structure, } \\
\text { strategy and rivalry; government effects; } \\
\text { institutions; culture; chance events), etc. }\end{array}$ \\
\hline & &
\end{tabular}

Figure 2. The mediating role of innovations as a factor of the firm's competitiveness

The model shows that both performance and innovations depend on the same pool of internal and external factors, which can have direct or indirect impacts on them. All these factors and their combinations can be referred to as primary or basic factors. These factors are basic, because they reflect the primary mix of resources and capabilities under given external conditions as in the classical production function. The resulting from these factors operational activities assure the firm everyday functioning. Unlike basic factors, the innovation-related ones are firm specific and lead to sustainable competitive advantages, as it is difficult to imitate the new combinations (Gruber et al., 2010, p. 1347). These factors belong to the "residual element" of the production function, which includes technological progress and innovations (Solow, 1957).

The assumption that both innovations and performance have the same groups of antecedents and determinants along with the innovations' own impact on performance allows for suggesting the first proposal:

\section{P1. When innovations influence} performance, these will mediate the effects of some basic factors (which impact both innovations and performance) on performance.
The previous studies have shown that different types of innovations are interrelated and influence each other, albeit to a different degree. Consequently, the innovations can also influence firm performance directly or indirectly (through their interaction). While some research finds that product innovation impact more directly performance, others studies emphasise the underpinning effect of process innovation for successful product launches (Piening and Salge, 2015). Therefore, the theories of innovation need to account for the mutual interaction of types of innovation (Reichstein and Salter, 2006, p. 676). The second proposal is the following:

P2. Innovations can influence directly or indirectly (through their interactions) firm performance.

Gunday et al. (2011, p. 671) find that the innovative performance is directly and positively affected by organizational, product and marketing innovations, while process innovation influences performance indirectly through product innovation. Organizational and marketing innovations have both direct and indirect (through product innovation) effects on innovative performance. Camisón and Villar-López (2014) also reveal that the product innovation capabilities mediate the 


\section{Articles}

relationships between process innovation and firm performance. The results of Vladimirov (2016) show that product innovations mediate fully the effects of process innovations and external factors and partially the effects of internal factors on performance. The third proposal specifies the effects of the innovations' interaction:

P3. The type(s) of innovation, which impact directly performance, will mediate the effects of other innovations and basic factors on performance.

The findings supporting the innovation as a mediator do not imply that innovation is the only means to achieve superior performance. Other factors such as technology, R\&D capacity, demand, price, etc., influence also competitiveness (Fagerberg et al., 2007). Business performance does not coincide always with the innovativeness (Coad and Rao, 2008, p. 30), and the innovation success is not always guaranteed (Baker and Sinkula, 2005). There are cases when innovations are too expensive (O'Connor and Rice, 2013), inappropriate or badly executed, and consequently the performance would depend exclusively on firm basic factors. For example, access to finance, resources, location, institutional context, etc. might be more important than innovations for performance (Lin and Chen, 2007). As García-Sánchez et al. (2019) show the high costs and the insufficient government support for sustainability innovations may have a negative effect on competitiveness. The results of Santos et al. (2014, p. 533) indicate little evidence that innovation characteristics of the sample of Brazilian firms in one period have a positive impact on firm performance in the next period. Under economic crises companies may be interested more by improving cash flows, increasing access to finance, etc., than by innovations. In these situations, the performance will depend mainly on firm basic factors. It follows that:

P4. When innovations have no impact on performance or this impact is insignificant, the performance will depend mainly on firm basic factors.

According to the reviewed theories, the performance that is based on innovations differs from the performance based on operational effectiveness. Striving for operational effectiveness leads to temporary benefits because of the uniformity of the resulting best practices (Porter, 1996, p. 63). Teece (2014, p. 33) considers that with globalisation, barriers to the transfer of ordinary capabilities have been reduced, which means that many ordinary activities even on the level of "best practices" are no longer critical to competitive advantage. Therefore, the advantages of firms without innovations are not sustainable, while innovative firms may achieve long lasting advantages. This leads to the next proposal:

P5. The basic factors, which impact both firm innovations and performance, will be most important for achieving sustainable competitive advantages.

These proposals reveal some understudied associations between competitiveness factors at a firm level and innovations, and their common impact on performance. For example, positing innovations at the same level of analysis as the other competitiveness factors, ignores the fact that some of these factors are also innovation antecedents and determinants. Hence these relationships remain hidden.

From the first proposal it follows that when innovations influence performance, these mediate the impact of some of the basic factors, although other primary factors may 


\section{Articles}

also have direct effects on performance. The results of Vladimirov (2016, p. 224) show that while innovations influence positively the manufacturing firms' performance, the two basic factors (firm size and export orientation) have the strongest total (direct and indirect) effects on performance.

The mediating role of leading type(s) of innovations (which impact directly performance) between other types of innovations and performance is conceptually supported by the innovations' interaction. This role is reflected in the second and third proposals. From these it follows that the innovative activities need to be focused on many aspects simultaneously such as new products, organizational and marketing practices, and process technologies (Drejer, 2002). The fourth proposal reveals the cases of unsuccessful innovations, which have also been identified in the literature (Lin and Chen, 2007, p. 125). In these situations, the performance will depend exclusively on the firm's internal and external competitiveness factors. The fifth proposal suggests that some basic factors are most important as they can influence both innovations and performance. These factors, however, might be different for different industries (Magliulo, 2013).

Therefore, these proposals hep to understand better the mediating role of innovations as a factor of the firm's competitiveness along with other internal and external factors. The proposals conceptually justify how the innovations can contribute to the competitiveness at a firm level.

\section{Conclusion}

The paper aims to clarify conceptually the mediating role of innovations as a firm's competitiveness factor. The review of relevant theories (Porter's framework, RBV, DCV, and
Mediating Role of Innovations as a Factor of Firm's

Competitiveness

configurational approach) and the related empirical research find that these theories converge to some degree in their assumptions and recommendations. Combining these approaches results in a framework which encompasses firm internal and external sources of competitiveness. These sources and their combinations constitute the firm primary (basic) factors.

The paper reveals that both competitiveness and innovation depend on the same groups of firm internal and external factors. This leads to the enlarged conceptual model of firm competitiveness, in which these factors are positioned on two levels. The first level retains the traditional distinction between the firm external and internal factors, while the second one supplements the innovationrelated factors.

The paper does not introduce new competitiveness factors, rather it sheds light on the mechanism of how the firm's basic factors and innovations impact performance. Being determined by some of the internal and external factors and having their own impact on performance, the innovations mediate the influence of these factors on performance. Following the innovations' interaction, it is shown that innovations can influence directly or indirectly firm performance. If there is a leading type(s) of innovation, which impacts directly performance, it will mediate the effects of some other innovations and basic factors on performance. The mediating role of innovations can help identify the relative significance of innovations to the firm's competitiveness in comparison to other factors. It can also help explain why there is still no consensus on the importance of innovations for performance (Santos et al., 2014). 


\section{Articles}

The interdependence between firm basic factors and innovations provides a means to connect the main theories of firm competitiveness with innovation studies in a single framework. While most of the existing research have analysed certain aspects of competitiveness in isolation (Singh et al., 2008), the proposed model responds to the need for a more holistic approach towards competitiveness. Thereby, the paper contributes to the competitiveness literature at a firm level.

The policy implications are that in general, the innovation promotion programmes aim to support the new products/services by neglecting the underpinning role of other types of innovations and basic factors. However, the model suggests that arriving at a successful product/service innovation requires significant changes in organizational, technological, and marketing processes. Therefore, these programmes should distribute funds to support the whole process of innovation.

Based on the fifth proposal, the implications for managers are that they need to identify basic factors from different domains (structure, staff, sales, marketing, etc.), which impact both firm innovations and performance. Developing these primary factors may result into both higher innovativeness and greater competitiveness.

The paper is limited in scope to the analysis of selected theories that are considered the most appropriate for the study of the firm's competitiveness. It is acknowledged that other theories from evolutionary economics, institutional theories, etc. can also contribute to this topic. The other restrictions refer to not discussing incremental vs radical innovations (Slater et al., 2014). As the proposed model is conceptual, the derived from it propositions are also general. Further empirical researches could test more specific hypotheses. The studies under this model, however, may be complicated when looking for determinants and performance effects of more than one innovation. This is because different innovations may have both different determinants (Edquist, 2001, p. 7) and different effects on competitiveness (Hermundsdottir and Aspelund, 2021, p. 14). These issues open an important area of further research.

Despite these limitations, the paper contributes to the clarification of the complex relations between innovation antecedents and determinants, innovation itself, and performance consequences.

\section{References}

Aldieri, L., Sena, V., Vinci, C.P. 2018. Domestic R\&D spillovers and absorptive capacity: Some evidence for US, Europe and Japan. International Journal of Production Economics, 198, 38-49

Allred B.B. and Swan K.S. 2005. The mediating role of innovation on the influence of industry structure and national context on firm performance. Journal of International Management, 11, 229-252.

Armstrong, C.E. and Shimizu, K. 2007. A Review of Approaches to Empirical Research on the Resource-Based View of the Firm. Journal of Management, 33(6), 959-986.

Artz, K.W., Norman, P.M., Hatfield, D.E. and Cardinal, L.B. 2010. A Longitudinal Study of the Impact of R\&D, Patents, and Product Innovation on Firm Performance. Journal of Product Innovation Management, 27, 725-740.

Awuah, G. B. and Amal, M. 2011. Impact of globalization. The ability of less developed countries' (LDCs') firms to cope with opportunities and challenges, European Business Review, 23(1), 120-132.

Azar, G. and Ciabuschi, F. 2017. Organizational innovation, technological innovation, and export performance: The effects of innovation 


\section{Articles}

radicalness and extensiveness. International Business Review, 26(2), 324-336.

Bakan, I. and Doğan, I. 2012. Competitiveness of the industries based on the Porter's diamond model: and empirical study. IJRRAS, 11(3), 441-455.

Ballot, G., Fakhfakh, F., Galia, F. and Salter, A. 2015. The fateful triangle: Complementarities in performance between product, process and organizational innovation in France and the UK. Research Policy, 44, 217-232.

Baker, W.E. and Sinkula, J.M. 2005. Market orientation and the new product paradox. Journal of Product Innovation Management, 22, 483-502.

Balashova, E.S. and Gromova, E.A. 2016. Resource-based view as a perspective management model in Russian reality. Problems and Perspectives in Management, 14(2-2), 325-330.

Balkin, D.B. and Markman, G.D., GomezMejia, L.R. 2000. Is CEO pay in hightechnology firms related to innovation? Academy of Management Journal, 43(6), 1118-1129

Barney, J.B. 1991. Firm resources and sustained competitive advantage. Journal of Management, 17(1), 99-120.

Barney, J.B. 1997. Gaining and Sustaining Competitive Advantage. Reading, MA, Addison-Wesley Publishing Company.

Becheikh, N., Landry, R. and Amara, N. 2006. Lessons from innovation empirical studies in the manufacturing sector: A systematic review of the literature from 1993-2003. Technovation, 26, 644-664.

Black, J.A. and Boal, K.B. 1994. Strategic Resources: Traits, Configurations and Paths to Sustainable Competitive Advantage. Strategic Management Journal, 15, 131-148.

Bogers, M., Zobel, A-K., Afuah, A. et al. 2017. The open innovation research landscape: established perspectives and emerging themes across different levels of analysis, Industry and Innovation, 24(1), 8-40.
Mediating Role of Innovations as a Factor of Firm's

Competitiveness

Buckley, P.J., Christopher, L.P. and Prescott, K. 1988. Measures of International Competitiveness: A Critical Survey. Journal of Marketing Management, 4(2), 175-200.

Camisón, C. and Villar-López, A. 2014. Organisational innovation as an enabler of technological innovation capabilities and firm performance. Journal of Business Research, 67 (1), 2891-2902.

Carayannis, E. and Wang, V. 2012. Competitiveness Model - A Double Diamond. Journal of the Knowledge Economy, 3(3), 280293.

Cavusgil, E., Seggie, S. and Talay, M.B. 2007. Dynamic Capabilities View: Foundations and Research Agenda. The Journal of Marketing Theory and Practice, 15(2),159-166.

Chang, W., Franke, G.R, Butler, T.D., Musgrove, C.F. and Ellinger, A.E. 2014. Differential Mediating Effects of Radical and Incremental Innovation on Market Orientation-Performance Relationship: A Meta-Analysis. Journal of Marketing Theory and Practice, 22(3), 235249.

Chang, Y.-Y., Hughes, M. and Hotho, S. 2011. Internal and external antecedents of SMEs' innovation ambidexterity outcomes. Management Decision, 49(10), 1658-1676.

Chatzoglou, P. and Chatzoudes, D. 2018. The role of innovation in building competitive advantages: an empirical investigation. European Journal of Innovation Management, 21(1), 44-69.

Chen, Y., Podolski, E. J. and Veeraraghavan, M. 2017. National culture and corporate innovation. Pacific-Basin Finance Journal, 43, 173-187.

Cheng, C.C. and Krumwiede, D. 2010. The effects of market orientation and service innovation on service industry performance: An empirical study. Operational Management Research, 3,161-171.

Chesbrough, H., Vanhaverbeke, W. and West, J. 2006. Open Innovation: Researching a New Paradigm. Oxford, Oxford University Press. 


\section{Articles}

Chew, D. A. S., Yan, S. and Cheah, C. Y. J. 2008. Core Capability and Competitive Strategy for Construction SMEs in China. Chinese Management Studies, 2(3), 203-214.

Coad, A. and Rao, R. 2008. Innovation and Firm Growth in "Complex Technology" Sectors: A Quantile Regression Approach. Research Policy, 37, 633-648.

Cohen, W.M. and Levinthal, D.A. 1990. Absorptive capacity: A new perspective on learning and innovation. Administrative Science Quarterly, 35(1), 128-152.

Collins, C. J. 2020. Expanding the resourcebased view model of strategic human resource management. The International Journal of Human Resource Management, 1-28.

Collis, D.J. 1994. How Valuable Are Organizational Capabilities? Strategic Management Journal, 15, 143-152.

Cornelissen, J. 2017. Editor's comments: Developing propositions, a process model, or a typology? Addressing the challenges of writing theory without a boilerplate. Academy of Management Review, 42(1), 1-9.

Crossan, M.M., and Apaydin, M. 2010. A MultiDimensional Framework of Organizational Innovation: A Systematic Review of the Literature. Journal of Management Studies, 47(6), 1154-1191.

Damanpour, F, Walker, R. and Avellaneda, C.N. 2009. Combinative Effects of Innovation Types and Organizational Performance: A Longitudinal Study of Service Organizations. Journal of Management Studies, 46(4), 650675.

Damanpour, F. 1991. Organizational innovation: a meta-analysis of effects of determinants and moderators. Academy of Management Journal, 34 (3), 555-590.

Drnevich, P.L., Aldas, P. and Kriauciunas, A.P. 2011. Clarifying the conditions and limits of the contributions of ordinary and dynamic capabilities to relative firm performance. Strategic Management Journal, 32, 254-279.
Edquist, C. 2001, The Systems of Innovation Approach and Innovation Policy: An account of the state of the art. Available at: https:// w w w. rese a r c h g a t e. n e t / publication/228823918_The_Systems_of_ Innovation_Approach__ and_Innovation_ Policy_An_Account_of_the_State_of_the_ Art, [Accessed 27 March 2021].

Eisenhardt, K.M. and Martin, J.A. 2000. Dynamic capabilities: what are they? Strategic Management Journal, 21(10/11), 1105-1121.

Fagerberg, J. 1996. Technology and competitiveness. Oxford Review of Economic Policy, 12(3), 39-51.

Fagerberg, J., Mowery, D.C. and Nelson, R.R. 2004. The Oxford Handbook of Innovation. New York, Oxford University Press.

Fagerberg, J., Srholec, M. and Knell, M. 2007. The Competitiveness of Nations: Why some countries prosper while others fall behind. World Development, 35(10), 1595-1620.

Fahy, J. 2002. A resource-based analysis of sustainable competitive advantage in a global environment, International Business Review, 11(1), 57-77

Ferreira, J. J., Fernandes, C. I. and Ratten, V. 2017. Entrepreneurship, innovation and competitiveness: what is the connection? International Journal of Business and Globalisation, 18(1), 73-95.

Fiss, P.C. 2007. A Set-Theoretic Approach to Organizational Configurations. Academy of Management Review, 32 (4), 1180-1198.

Foss, K., Foss, N. J. and Klein, P. G. 2007. Original and derived judgment: $A n$ entrepreneurial theory of economic organisation. Organisation Studies, 28, 1-20.

Freel, M. S. 2005. Patterns of innovation and skills in small firms, Technovation, 25, 123 134.

Furnival, J., Boaden, R. and Walshe, K. 2019, A dynamic capabilities view of improvement capability. Journal of Health Organization and Management, 33(7/8), 821-834. 


\section{Articles}

Furrer, O., Sudharshan, D., Thomas, H. and Alexandre, M.T.2008. Resource configurations, generic strategies, and firm performance. Exploring the parallels between resourcebased and competitive strategy theories in a new industry. Journal of Strategy and Management, 1(1), 15-40.

Galbreath, J. 2005. Which resources matter the most to firm success? An exploratory study of resource-based theory. Technovation, 25(9), 979-987.

García-Sánchez, I.M., Gallego-Álvarez, I. and Zafra-Gómez, J.L. 2019. Do the ecoinnovation and ecodesign strategies generate value added in munificent environments? Business Strategy and the Environment, 29(3), 10211033.

Gellweiler, C. 2018. Cohesion of RBV and Industry View for Competitive Positioning. Strategic Management, 23(2), 3-12.

Gök, O. and Peker, S. 2016. Understanding the links among innovation performance, market performance and financial performance. Review of Managerial Science, 11(3), 605-631.

Grant, R.M. 2002. Contemporary Strategic Analysis (4th ed). Oxford, Blackwell Publishers.

Grimpe, C. and Kaiser, U. 2010. Balancing Internal and External Knowledge Acquisition: The Gains and Pains from R\&D Outsourcing. Journal of Management Studies, 47(8), 14831509.

Gruber, M., Heinemann, F., Brettel, M. and Hungeling, S. 2010. Configurations of resources and capabilities and their performance implications: an exploratory study on technology ventures. Strategic Management Journal, 31, 1337-1356.

Gunday, G., Ulusoy, G., Kilic, K. and Alpkan, L. 2011. Effects of innovation types on firm performance. International Journal of Production Economics, 133, 662-676.

Gupta, P., Guha, S. and Krishnaswami, S. 2013. Firm growth and its determinants.
Mediating Role of Innovations as a Factor of Firm's Competitiveness

Journal of Innovation and Entrepreneurship, 2(1), 1-14.

Gupta, S., Malhotra, N.K., Czinkota, M. and Foroudi, P. 2016. Marketing innovation: A consequence of competitiveness. Journal of Business Research, 69, 5671-5681.

Hall, R. 1992. The strategic analysis of intangible resources. Strategic Management Journal, 13, 135-144.

Harms, R., Kraus, S. and Schwarz, E. 2009. The suitability of the configuration approach in entrepreneurship research. Entrepreneurship \& Regional Development, 21(1), 25-49.

Helfat, C. and Martin, J. 2015. Dynamic managerial capabilities: Review and assessment of managerial impact on strategic change. Journal of Management, 41(5), 12811312.

Helfat, C. and Peteraf, M. 2003. The dynamic resource-based view: capability lifecycles. Strategic Management Journal, 24(10), 9971010.

Hermundsdottir, F. and Aspelund, A. 2021. Sustainability innovations and firm competitiveness: A review. Journal of Cleaner Production, 280, Part 1, 124715

Hernandez-Mogollón, R., Cepeda-Carrión, G., Cegarra-Navarro, J.G. and Leal-Millan, A. 2010. The role of cultural barriers in the relationship between open-mindedness and organizational innovation. Journal of Organizational Change Management, 23(4), 360-376.

Hervas-Oliver, J.L., Sempere-Ripoll, F. and Boronat-Moll, C. 2014. Process innovation strategy in SMEs, organizational innovation and performance: a misleading debate? Small Business Economics, 43, 873-886.

Homburg, C., Jensen, O. and Krohmer, $\mathrm{H}$. 2008. Configurations of Marketing and Sales: A Taxonomy. Journal of Marketing, 72, 133154

Hong, S., Oxley, L. and McCann. P. 2012. A Survey of the Innovation Surveys. Journal of Economic Surveys, 26 (3), 420-444. 


\section{Articles}

Hoonsopon, D. and Ruenrom, G. 2012. The impact of organizational capabilities on the development of radical and incremental product innovation and product innovation performance. Journal of Managerial Issues, 24(3), 250-276.

Hullova, D., Trott, P. and Don, S.C. 2016. Uncovering the reciprocal complementarity between product and process innovation. Research Policy, 45(5), 929-940.

Hult, G. T. M., and Ketchen, D. J. 2001. Does market orientation matter? a test of the relationship between positional advantage and performance. Strategic Management Journal, 22(9), 899-906.

lammarino, S. and McCann, P. 2006. The structure and evolution of industrial clusters: Transactions, technology and knowledge spillovers. Research Policy, 35, 1018-1036.

IMD and WEF. 1993. The World Competitiveness Report. Lausanne, Switzerland.

Jaakkola, E. 2020. Designing conceptual articles: four approaches. AMS Review, 10,18-26.

Jiménez Jiménez, D., Cegarra-Navarro, J.G., Perin, M.G., Sampaio, C.H. and Lengler, J.B. 2014, Entrepreneurial capacities as antecedents of business performance in Brazilian firms. Canadian Journal of Administrative Sciences, 31, 90-103.

Jiménez-Jiménez, D., and Sanz-Valle, R. 2011. Innovation, organizational learning, and performance. Journal of Business Research, 64(4), 408-417.

Jin, B. and Moon, H-C. 2006. The diamond approach to the competitiveness of Korea's apparel industry: Michael Porter and beyond. Journal of Fashion Marketing and Management, 10(2), 195-208

Julienti, L., Bakar, A. and Ahmad, H. 2010. Assessing the relationship between firm resources and product innovation performance. Business Process Management Journal, 6(3), 420-435.
Kamasak, R. 2017. The contribution of tangible and intangible resources, and capabilities to a firm's profitability and market performance. European Journal of Management and Business Economics, 26(2), 252-275.

Keskin, H. 2006. Market orientation, learning orientation, and innovation capabilities in SMEs. An extended model, European Journal of Innovation Management, Vol. 9, No. 4, 396 - 417.

Ketels, C. 2013. Recent research on competitiveness and clusters: what are the implications for regional policy? Cambridge Journal of Regions, Economy and Society, 6(2), 269-284,

Keupp, M., Palmié, M. and Gassmann, O. 2012. The strategic management of innovation: A systematic review and paths for future research. International Journal of Management Reviews, 14, 367-390.

Kleinschmidt, E. J. and Cooper, R. G. 1991. The impact of product innovativeness on performance. Journal of Product Innovation Management, 8 (4), 240 - 251.

Kollmann, T. and Stöckmann, C. 2014. Filling the Entrepreneurial Orientation-Performance Gap: The Mediating Effects of Exploratory and Exploitative Innovations. Entrepreneurship Theory and Practice, 38(5), 1001-1026.

Kostopoulos, K., Papalexandris, A., Papachroni, M. and loannou, G. 2011. Absorptive capacity, innovation, and financial performance. Journal of Business Research, 64(12), 1335-1343.

Lall, S. 2001. Competitiveness, technology and skills. Cheltenham, UK, Edward Elgar Publishing.

Lavie, D. 2006. The competitive advantage of interconnected firms: an extension of the resource-based view. Academy of Management Review, 31(3), 638-658.

Lee, R., Lee, J-H. and Garrett, T.C. 2019. Synergy effects of innovation on firm performance. Journal of Business Research, $99,507-515$. 


\section{Articles}

Lin, C.Y. and Chen, M.Y. 2007. Does innovation lead to performance? An empirical study of SMEs in Taiwan. Management Research News, 30(2), 115-132.

López-Fernández, M.C., Serrano-Bedia, A.M. and Gómez-López, R. 2011. Factors Encouraging Innovation in Spanish Hospitality Firms. Cornell Hospitality Quarterly, 52(2), 144-152.

Love, J.H. and Roper, S. 2015. SME innovation, exporting and growth: A review of existing evidence. International Small Business Journal, 33(1), 28-48.

Lundvall, B. 1998. Why study systems and national styles of innovation? Technology Analysis and Strategic Management, 10(4), 407-421.

Magliulo, A. 2013. A Model for the Sustainable Competitiveness of Tourism Destinations. Available at: https://www.researchgate.net/ publication/267294791_A_Model_for_the Sustainable_Competitiveness_of_Tourism_ Destinations [Accessed on 4 May 2021].

Mahoney, J.T. and Pandian, J. 1992. The resource-based view within the conversation of strategic management. Strategic Management Journal, 13(5), 363-380.

Man, W.Y., Lau, T. and Chan, K.F. 2002. The Competitiveness of Small and Medium Enterprises. A Conceptualization with Focus on Entrepreneurial Competencies. Journal of Business Venturing, 17(1), 123-142.

McAdam, R., Reid, R. and Shevlin, M. 2014. Determinants for innovation implementation at SME and inter SME levels within peripheral regions. International Journal of Entrepreneurial Behaviour \& Research, 20(1), 66-90.

McEvily, S.K. and Chakravarthy, B. 2002. The Persistence of Knowledge-Based Advantage: An Empirical Test for Product Performance and Technological Knowledge. Strategic Management Journal, 23(4), 285-305.

McNally, R.C., Cavusgil, E. and Calantone, R.J. 2010. Product Innovativeness Dimensions and Their Relationships with Product
Mediating Role of Innovations as a Factor of Firm's Competitiveness

Advantage, Product Financial Performance, and Project Protocol. Journal of Product Innovation Management, 27, 991-1006.

Meyer, A.D., Tsui, A.S. and Hinings, C.R. 1993. Configurational approaches to organizational analysis. Academy of Management Journal, 36, 1175-1195.

Miller, D. 1996. Configuration revisited. Strategic Management Journal, 17, 505-512.

Momaya, K.S. 2019. The Past and the Future of Competitiveness Research: A Review in an Emerging Context of Innovation and EMNEs. International Journal of Global Business and Competitiveness, 14, 1-10.

Mytelka, L.K. 1999. Competition, Innovation and Competitiveness: A Framework for Analysis. In L.K. Mytelka (ed.) Competition, Innovation and Competitiveness in Developing Countries, pp. 15-27, OECD, Paris.

Naranjo-Gil, D. 2009. The Influence of Environmental and Organizational Factors on Innovation Adoptions: Consequences for Performance in Public Sector Organizations. Technovation, 29(12), 810-818.

Newbert, S.L. 2007. Empirical research on the resource-based view of the firm: an assessment and suggestions for future research. Strategic Management Journal, 28, 121-146.

Ngo, L.V. and O'Cass, A. 2013. Innovation and business success: The mediating role of customer participation. Journal of Business Research, 66(8), 1134-1142.

OECD. 2005. Oslo manual: Guidelines for collecting and interpreting innovation data. Paris, OECD.

O'Connor, G.C. and Rice, M.P. 2013. A comprehensive model of uncertainty associated with radical innovation. Journal of Product Innovation Management, 30(51), 2-18.

Oksanen, J. and Rilla, N. 2009. Innovation and entrepreneurship: new innovations as source for competitiveness in Finnish SMEs. International Journal of Entrepreneurship, 13, 35-48. 


\section{Articles}

Oral, E.L. and Mistikoglu, G. 2007. Competitive analysis of the Turkish brick industry - a case study for developing countries. Building and Environment, 42, 416-423

Ozgen, E. 2011. Porter's diamond model and opportunity recognition: a cognitive perspective. Academy of Entrepreneurship Journal, 17(2), 61-76.

Pavlou, P. A. and El Sawy, O. A. 2011. Understanding the Elusive Black Box of Dynamic Capabilities. Decision Sciences, 42(1), 239-273.

Peña-Vinces, J.C., Cepeda-Carrión, G. and Chin, W.W. 2012. Effect of ITC on the international competitiveness of firms. Management Decision, 50(6), 1045-1061.

Pertusa-Ortega, E.M., Molina-Azorin, J.F. and Claver-Cortés, E. 2010. Competitive strategy, structure and firm performance: A comparison of the resource-based view and the contingency approach. Management Decision, 48(8),1282-1303.

Piening, E.P., and Salge, T.O. 2014. Understanding the antecedents, contingencies, and performance implications of process Innovation: a dynamic capabilities perspective. Journal of Product Innovation Management, 32 (1), 80-97.

Porter, M. E. 1991. Towards a dynamic theory of strategy. Strategic Management Journal, 12, 95-117.

Porter, M.E. 1996. What is strategy? Harvard Business Review, 74(6), 61-78.

Porter, M.E. 1998. Competitive Strategy: Techniques for Analyzing Industries and Competitors: With a New Introduction. New York, The Free Press.

Prahalad, C.K. and Hamel, G. 1990. The Core Competence of the Corporation. Harvard Business Review, 68(3), 79-92.

Protogerou, A., Caloghirou, Y. and Lioukas, S. 2011. Dynamic capabilities and their indirect impact in firm performance. Industrial Corporate Change, 21(3), 615-647.
Raisch, S., Birkinshaw, J., Probst, G. and Tushman, M.L. 2009. Organizational ambidexterity: balancing exploitation and exploration for sustained performance. Organization Science, 20 (4), 685-695.

Rajapathirana, R. P. J. and Hui, Y. 2018. Relationship between innovation capability, innovation type, and firm performance. Journal of Innovation \& Knowledge, 3(1), 44-55.

Ramadani, V., Hisrich, R. D., Abazi-Alili, H., Dana, L.-P., Panthi, L. and Abazi-Bexheti, L. 2019. Product innovation and firm performance in transition economies: A multi-stage estimation approach. Technological Forecasting and Social Change, 140, 271-280

Reichstein, T. and Salter, A. 2006. Investigating the sources of process innovation among UK manufacturing firms. Industrial and Corporate Change, 15 (4), 653-682.

Ritter, T. and Gemünden, H.G. 2003. Interorganizational relationships and networks: an overview. Journal of Business Research, 56(9), 691-697.

Rosenbusch, N., Brinckmann, J. and Bausch, A. 2011. Is innovation always beneficial? A meta-analysis of the relationship between innovation and performance in SMEs, Journal of Business Venturing, 26 (4), 441-457.

Santos, D.F.L., Basso, L.F.C., Kimura, H. and Kayo, E.K. 2014. Innovation efforts and performances of Brazilian firms. Journal of Business Research, 67, 527-535

Sarasvathy, S. D. 2004. The Questions we Ask and the Questions we Care about: Reformulating Some Problems in Entrepreneurship Research. Journal of Business Venturing, 19(5), 707-717.

Schumpeter, J.A. 1934. The Theory of Economic Development. Cambridge, MA, Harvard University Press.

Simpson, M., Padmore, J. and Newman, N. 2012. Towards a new model of success and performance in SMEs. International Journal of Entrepreneurial Behavior \& Research, 18(3), 264-285 


\section{Articles}

Simpson, P.M., Siguaw, J.A. and Enz, C.A. 2006. Innovation orientation outcomes: the good and the bad. Journal of Business Research, 59, 1133-1141.

Singh, R.K., Garg, S.K. and Deshmukh, S.G. 2008. Strategy development by SMEs for competitiveness: a review. Benchmarking: An International Journal, 15(5), 525-547.

Sirikrai, S. B., and Tang, J. C. S. 2006. Industrial Competitiveness Analysis: Using the Analytic Hierarchy Process. Journal of High Technology Management Research, 17(1), 7183.

Sirmon, D.G, Hitt, M.A., Ireland, R.D. and Gilbert, B.A. 2011. Resource Orchestration to Create Competitive Advantage: Breadth, Depth, and Life Cycle Effects. Journal of Management, 37(5), 1390-1412

Siudek, J., and Zawojska, A. 2014. Competitiveness in the economic concepts, theories and empirical research. Oeconomia, 13 (1), 91-108.

Slater, S.F., Mohr, J.J. and Sengupta, S. 2014. Radical product innovation capability: Literature review, synthesis, and illustrative research propositions. Journal of Product Innovation Management, 31(3), 552-566.

Solow, R.M. 1957. Technical Change and the Aggregate Production Function. Review of Economics and Statistics, 39 (3), 312-320.

Souitaris, V. 2003. Determinants of Technological Innovation: Current Research Trends and Future Prospects. In Shavinina, L.V. (ed.). International Handbook on Innovation. pp. 514-529, Elsevier Science Ltd.

Srivastava, S., Sultan, A. and Chashti, N. 2017. Influence of innovation competence on firm level competitiveness: an exploratory study. Asia Pacific Journal of Innovation and Entrepreneurship, 11(1), 63-75.

Sumer, K. and Bayraktar, C. A. 2012. Business Strategies and Gaps in Porter's Typology: A Literature Review. Journal of Management Research, 4(3). 100-119.
Mediating Role of Innovations as a Factor of Firm's

Competitiveness

Sun, H., Fan, Z., Zhou, Y. and Shi, Y. 2010. Empirical research on competitiveness factors: Analysis of real estate industry of Beijing and Tianjin. Engineering, Construction and Architectural Management, 17(3), 240251.

Swoboda, B. and Olejnik, E. 2014. Linking Processes and Dynamic Capabilities of International SMEs: The Mediating Effect of International Entrepreneurial Orientation. Journal of Small Business Management, 54(1), 139-161.

Tang, J. and Murphy, P.J. 2012. Prior knowledge and new product and service introductions by entrepreneurial firms: the mediating role of technological innovation. Journal of Small Business Management, 50(1), 41-62.

Teece, D.J. 2014. A dynamic capabilitiesbased entrepreneurial theory of the multinational enterprise. Journal of International Business Studies, 45, 8-37

Teece, D.J. and Pisano, G. 1994. The dynamic capabilities of firms: An introduction. Industrial and Corporate Change, 3(3), 537-556.

Teece, D.J., Pisano, G. and Shuen, A. 1997. Dynamic Capabilities and Strategic Management. Strategic Management Journal, 18(7), 509-533.

Toppinen, A., Toivonen, R., Mutanen, A., Goltsev, V. and Tatti, N. 2007. Sources of competitive advantage in woodworking firms of Northwest Russia, International Journal of Emerging Markets, 2(4), 383-394

Tsai, P-H., Chen, C-J. and Yang, H-C. 2021. Using Porter's Diamond Model to Assess the Competitiveness of Taiwan's Solar Photovoltaic Industry. SAGE Open, 1-16, doi: 10.1177/2158244020988286

Ungerman, O.; Dedkova, J.; Gurinova, K. 2018. The impact of marketing innovation on the competitiveness of enterprises in the context of industry 4.0. Journal of Competitiveness, 10(2), 132-148. 


\section{Articles}

Uzkurt, C., Kimzan, H. S., \& Yılmaz, C. 2016. A Case Study of the Mediating Role of Innovation on the Relationship Between Environmental Uncertainty, Market Orientation, and Firm Performance. International Journal of Innovation and Technology Management, 13(06), 1750003.

Vega-Jurado, J., Gutíerrez-Gracia, A., Fernández-de-Lucio, I. and ManjarrésHenríquez, L. 2008. The effect of external and internal factors on firms' product innovation. Research Policy, 37(4), 616-632.

Vincent, L.H., Bharadwaj, S.G. and Challagalla, G.N. 2004. Does Innovation Mediate Firm Performance? A Meta-Analysis of Determinants and Consequences of Organizational Innovation. Available at: https:// smartech. gatech.edu/handle/1853/10731 [Accessed 19 March 2021].

Vladimirov, Z. 2016. Manufacturing SME innovations and performance: the mediating role of product innovation. International Review of Entrepreneurship, 14(2), 209-234.

Vogel, R. and Güttel, W.H. 2013. The Dynamic Capability View in Strategic Management: A Bibliometric Review. International Journal of Management Reviews, 15, 426-446.

Walker, R.M., Chen, J. and Aravind, D. 2015. Management innovation and firm performance: An integration of research findings. European Management Journal, 33(5), 407-422.

Wang, C.L. and Ahmed, P.K. 2007. Dynamic capabilities: a review and research agenda. The International Journal of Management Reviews, 9(1), 31-51.

Wang, Y. and Lin, J. 2013. An empirical research on knowledge management orientation and organizational performance: the mediating role of organizational innovation. African Journal of Business Management, 7(8), 604-612.
Wang, Y-L., Wang, Y-D. and Horng, R-Y. 2010. Learning and innovation in small and medium enterprises. Industrial Management \& Data Systems, 110(2), 175-192.

Wang, C.L., Senaratne, C. and Rafiq, M. 2015. Success traps, dynamic capabilities and firm performance. British Journal of Management, 26(1), 26-44.

Watchravesringkan, K., Karpova, E.E., Hodges, N.N. and Copeland, R. 2010. The competitive position of Thailand's apparel industry: Challenges and opportunities for globalization. Journal of Fashion Marketing and Management, 14(4), 576-597

Wernerfelt, B. 1984. A resource-based view of the firm. Strategic Management Journal, 5(2), 171-180.

Wiklund, J. and Shepherd, D. 2005, Entrepreneurial orientation and small business performance: a configurational approach. Journal of Business Venturing, 20, 71-91.

Winter, S.G. 2003. Understanding dynamic capabilities. Strategic Management Journal, 24(10), 991-995.

Zahra, S.A., Matherne, B.P. and Carleton, J.M. 2003. Technological resource leveraging and the internationalization of new ventures. Journal of International Entrepreneurship, 1(2), 163-186.

Zahra, S.A., Sapienza, H.J. and Davidsson, P. 2006. Entrepreneurship and Dynamic Capabilities: A Review, Model and Research Agenda. Journal of Management Studies, 43(4), 917-955.

Zaied, R.M.B. and Affes, H. 2016. The relationship between the sources of knowledge management, organizational innovation and organizational performance. International Journal of Information, Business and Management, 8(3), 185-206. 


\section{Appendix 1}

Table 1. Studies on firm level competitiveness under the basic theories

\begin{tabular}{|l|l|}
\hline \multicolumn{1}{|c|}{ Basic theories } & \multicolumn{1}{|c|}{ Some studies based on the respective theories } \\
\hline $\begin{array}{l}\text { Activity-based view } \\
\text { (Porter' framework) } \\
\text { (Porter, 1991, 1996, 1998) }\end{array}$ & $\begin{array}{l}\text { Jin and Moon, 2006; Oral and Mistikoglu, 2007; Sun et al., 2010; } \\
\text { Watchraversringkan et al., 2010; Ozgen, 2011; Bakan and Doğan, 2012; } \\
\text { Sumer and Bayraktar, 2012; Tsai, et al., 2021. }\end{array}$ \\
\hline $\begin{array}{l}\text { RBV - (Wernerfelt, 1984; Barney, 1991, 1997; Hall, } \\
\text { 1992; Mahoney and Pandian, 1992; Black and Boal, } \\
\text { 1994; Grant, 2002) }\end{array}$ & $\begin{array}{l}\text { Hult and Ketchen, 2001; Fahy, 2002; McEvily and Chakravarth, 2002; Foss } \\
\text { et alusa-Ortega et al., 2010; Sirmon et al., 2011; Balashova and Gromova, } \\
\text { 2016; Collins, 2020. }\end{array}$ \\
\hline $\begin{array}{l}\text { DCV - (Teece and Pisano, 1994; Collis, 1994; Teece } \\
\text { et al., 1997; Eisenhardt and Martin, 2000; Winter, } \\
\text { 2003; Helfat and Peteraf, 2003; Teece, 2014). }\end{array}$ & $\begin{array}{l}\text { Zahra et al., 2006; Wang and Ahmed, 2007; Cavusgil et al., 2007; Drnevich } \\
\text { and Martin, 2015; Furnival et al., 2019. }\end{array}$ \\
\hline $\begin{array}{l}\text { Configuration approach } \\
\text { (Miller, 1996; Meyer et al., 1993; Fiss, 2007 }\end{array}$ & $\begin{array}{l}\text { Wiklund and Shepherd, 2005; Furrer et al., 2008; Homburg et al., 2008; } \\
\text { Harms et al., 2009; Gruber et al., 2010; Swoboda and Olejnik, 2013. }\end{array}$ \\
\hline $\begin{array}{l}\text { Combining Porter's model, RBV, DCV, and } \\
\text { configuration approache }\end{array}$ & $\begin{array}{l}\text { Man et al., 2002; Chew et al., 2008; Sirikrai and Tang, 2006; Toppinen et al., } \\
\text { 2007; Furrer et al., 2008; Pavlou and Sawy, 2011; Awuah and Amal, 2011; } \\
\text { Carayannis and Wang, 2012; Simpson et al., 2012; Gupta et al., 2013. }\end{array}$ \\
\hline
\end{tabular}

Table 2. Research on internal and external antecedents and determinants of innovations

\begin{tabular}{|c|c|}
\hline $\begin{array}{l}\text { Types of antecedents and } \\
\text { determinants }\end{array}$ & Authors \\
\hline $\begin{array}{l}\text { Internal antecedents and } \\
\text { determinants of innovation } \\
\text { (main concepts) }\end{array}$ & $\begin{array}{l}\text { Tangible and intangible assets and capabilities (Julienti et al., 2010); Knowledge factors } \\
\text { (McAdam et al., 2014); Absorptive capacity (Cohen and Levinthal, 1990); Networking (Ritter } \\
\text { and Gemünden, 2003; Lavie, 2006); Human capital (Tang and Murphy, 2012); Organizational } \\
\text { learning (Wang et al., 2010); Staff training (Freel, 2005); Entrepreneur (Oksanen and Rilla, } \\
\text { 2009; Rosenbusch et al., 2011); R\&D (Grimpe and Kaiser, 2010). }\end{array}$ \\
\hline $\begin{array}{l}\text { Other internal antecedents and } \\
\text { determinants }\end{array}$ & $\begin{array}{l}\text { Firm size; age; structure; strategies; technology; IT; quality standards; foreign capital, and } \\
\text { others - (Becheikh et al., 2006; Hong et al., 2012) }\end{array}$ \\
\hline $\begin{array}{l}\text { External antecedents and } \\
\text { determinants of innovation } \\
\text { (main concepts) }\end{array}$ & $\begin{array}{l}\text { National innovation system (Lundvall, 1998); Clusters and geographical (regional) innovation } \\
\text { systems (lammarino and McCann, 2006; Ketels, 2013); Open innovation, "technological } \\
\text { exploration”, "technological exploitation”, and "organizational ambidexterity" (Chesbrough et } \\
\text { al., 2006; Bogers et al., 2017; Raisch et al., 2009); Organisational culture (Hernández-Mogollon } \\
\text { et al., 2010; Chen et al., 2017). }\end{array}$ \\
\hline $\begin{array}{l}\text { Other external antecedents and } \\
\text { determinants of innovation }\end{array}$ & $\begin{array}{l}\text { Access to information; access to finance; intellectual property rights protection; networking; } \\
\text { internationalisation; industry sector; competitive structure; location and region; government } \\
\text { policies - (Souitaris, 2003; Becheikh et al., 2006; Oksanen and Rilla, 2009; Hong et al., 2012) }\end{array}$ \\
\hline $\begin{array}{l}\text { Combining internal and external } \\
\text { innovation antecedents and } \\
\text { determinants }\end{array}$ & $\begin{array}{l}\text { - The models with both internal and external factors explain innovative performance better } \\
\text { than models that include only one type of factor (Vega-Jurado et al., 2008). } \\
\text { - Combining the two groups of factors leads to better understanding of the antecedents of } \\
\text { innovation (Naranjo-Gil, 2009); } \\
\text { - Links between SMEs innovation, export and growth is based on firm's internal (assets and } \\
\text { capabilities) and external enablers (Love and Roper, 2015); } \\
\text { - Both firm-level characteristics and national innovation system are key factors that determine } \\
\text { firm's innovation capacities (Carayannis and Wang, 2012). }\end{array}$ \\
\hline
\end{tabular}




\section{Articles}

Table 3. Studies on innovation-performance relationships

\begin{tabular}{|c|c|}
\hline Types of relationships & Authors \\
\hline Positive relations & Rosenbusch et al., 2011; Ngo and 0'Cass, 2013 \\
\hline Negative relations & Balkin et al., 2000; Simpson et al., 2006 \\
\hline $\begin{array}{l}\text { Negative direct relationship between innovation and financial performance, } \\
\text { while market performance reverses this negative effect to a positive total } \\
\text { influence through its suppression effect }\end{array}$ & Gök and Peker, 2016 \\
\hline Lack of relations & Zaied and Affes, 2016 \\
\hline U shape form of the relationships between innovation and performance & Kleinschmidt and Cooper, 1991 \\
\hline Product innovations are positively associated with firm performance & $\begin{array}{l}\text { Fagerberg et al., 2004; McNally et al., 2010; } \\
\text { Ramadani et al., 2019 }\end{array}$ \\
\hline Process innovations is an important source of firm performance & $\begin{array}{l}\text { Reichstein and Salter, 2006; Keupp et al., 2012; } \\
\text { Piening and Salge, } 2014\end{array}$ \\
\hline Organizational innovations have a positive impact on firm performance & Lin and Chen, 2007; Azar and Ciabuschi, 2017 \\
\hline Marketing innovations lead to the increased competitiveness & Gupta et al., 2016; Ungerman et al., 2018 \\
\hline $\begin{array}{l}\text { Firms which develop simultaneously technical and organizational innovations } \\
\text { achieve competitive advantage }\end{array}$ & $\begin{array}{l}\text { Damanpour et al., 2009; Hervas-Oliver et al., 2014; } \\
\text { Lee et al. (2019) }\end{array}$ \\
\hline $\begin{array}{l}\text { Firms that are closer to the world technology frontier tend to benefit more } \\
\text { from knowledge spillovers }\end{array}$ & Aldieri et al., 2018 \\
\hline The relationship between innovation and performance is still an open question & Jiménez-Jiménez and Sanz-Valle, 2011 \\
\hline
\end{tabular}

Table 4. Mediating role of innovations as a factor of firm's competitiveness

\begin{tabular}{|c|c|}
\hline Types of innovation mediations & Authors \\
\hline Innovations partially mediate the effects of certain antecedents and performance & Vincent et al., 2004 \\
\hline $\begin{array}{l}\text { Investment in innovation mediates the relationships between industry dynamism, country's patent } \\
\text { protection and firm performance }\end{array}$ & Allred and Swan, 2005 \\
\hline $\begin{array}{l}\text { The innovation performance mediates fully the influence of external knowledge and absorptive } \\
\text { capacity on financial performance }\end{array}$ & Kostopoulos et al., 2011 \\
\hline $\begin{array}{l}\text { Radical and incremental product innovations mediate the impact of both culture and structure on } \\
\text { marketing and financial performance }\end{array}$ & $\begin{array}{l}\text { Hoonsopon and } \\
\text { Ruenrom, } 2012 \\
\end{array}$ \\
\hline $\begin{array}{l}\text { Organizational innovation partially mediates the relationship between knowledge management } \\
\text { orientation and performance }\end{array}$ & Wang and Lin, 2013 \\
\hline $\begin{array}{l}\text { Mediating role of the ICT use as a factor enhancing the international competitiveness of SMEs from } \\
\text { developing countries }\end{array}$ & Peña-Vinces et al., 2012 \\
\hline Product innovation mediates the relationship between environment uncertainty and firm performance & Uzkurt et al., 2016 \\
\hline $\begin{array}{l}\text { Innovative performance is directly and positively affected by organizational, product and marketing } \\
\text { innovations, while process innovation influences performance indirectly through product innovation }\end{array}$ & Gunday et al., 2011 \\
\hline $\begin{array}{l}\text { Product innovation capabilities mediate the relationships between process innovation and firm } \\
\text { performance }\end{array}$ & $\begin{array}{l}\text { Camisón and Villar- } \\
\text { López, } 2014\end{array}$ \\
\hline $\begin{array}{l}\text { Product innovations mediate fully the effects of process innovations and external factors and partially } \\
\text { the effects of internal factors on performance }\end{array}$ & Vladimirov, 2016 \\
\hline \multicolumn{2}{|l|}{ Innovation as a mediator between firm's strategic orientations and performance } \\
\hline $\begin{array}{l}\text { MO indirectly impacts firm performance via firm innovativeness and learning orientation; firm } \\
\text { innovativeness positively and directly affects firm performance }\end{array}$ & Keskin, 2006 \\
\hline $\begin{array}{l}\text { The impact of customer and competitor orientations on new service performance is mediated by } \\
\text { service innovation }\end{array}$ & $\begin{array}{l}\text { Cheng and Krumwiede, } \\
2010\end{array}$ \\
\hline $\begin{array}{l}\text { LO and radical innovation mediate completely the influence of EO on performance. Radical innovation } \\
\text { mediates partially the impact of LO on performance, while LO and radical innovation influence directly } \\
\text { and positively firm performance }\end{array}$ & $\begin{array}{l}\text { Jiménez Jiménez et al., } \\
2014\end{array}$ \\
\hline Both the explorative and the exploitative innovations mediate the influence of EO on firm pe & $\begin{array}{l}\text { Kollmann and } \\
\text { Stöckmann, } 2014\end{array}$ \\
\hline $\begin{array}{l}\text { Radical and incremental innovation play differential mediating roles on the MO - performance } \\
\text { relationship }\end{array}$ & Chang et al., 2014 \\
\hline
\end{tabular}

